Original Research Article

\title{
Antibiotic sensitivity pattern of bacterial isolates from urine samples of admitted patients with urinary tract infection in a tertiary care teaching hospital of Tripura, India: a hospital record based study
}

\author{
Uttam K. Das, Prithul Bhattacharjee*, Shubhaleena Debnath, Maitrayee Chakraborty, \\ Ranjib Ghosh, Lakshman Das, Dipankar Chakraborty
}

Department of Pharmacology, Tripura Medical College \& Dr. BRAM Teaching Hospital, Agartala, Tripura, India

Received: 04 March 2018 Accepted: 10 March 2018

*Correspondence to: Dr. Prithul Bhattacharjee, Email: drprithulb@gmail.com

Copyright: (C) the author(s), publisher and licensee Medip Academy. This is an openaccess article distributed under the terms of the Creative Commons Attribution NonCommercial License, which permits unrestricted noncommercial use, distribution, and reproduction in any medium, provided the original work is properly cited.

\begin{abstract}
Background: Urinary tract infection (UTI) being one of the most common and a serious health problem both in the community and hospital settings each year worldwide, the emergence of antibiotic resistance in the management of UTI is a serious public health issue. The present study will analyse the antimicrobial sensitivity pattern of pathogens isolated from the urine samples of admitted patients suffering from UTI in Tripura Medical College and Dr. B.R. Ambedkar Memorial Teaching Hospital (TMC).

Methods: This was a hospital record-based study. The urine samples of clinically diagnosed UTI patients admitted in various departments of the hospital during the study period were included. The reports of culture and sensitivity testing of the samples were collected. The results were interpreted according to the guidelines of the Clinical and Laboratory Standards Institute (CLSI).

Results: During the 12-month study period, a total of 752 urine samples were analysed. Enterococcus (43.75\%) was the most frequently isolated bacteria, followed by E. coli $(28.45 \%)$ and Klebsiella (14.89\%). Enterococcus was highly sensitive $(\mathrm{p}<0.001)$ to vancomycin $(95.33 \%)$, E. coli was mostly sensitive to nitrofurantoin $(83.65 \%)$ and Klebsiella mainly sensitive to imipenem $(75.49 \%)$. Conclusions: The study showed that positive urine culture with the antibiotic sensitivity of the isolates is very important for antimicrobial therapy, as antibiotic resistance is a worldwide problem which causes ineffectiveness of treatment.
\end{abstract}

Keywords: Antibiotic resistance, Enterococcus, E. coli, Klebsiella, Urinary tract infection

\section{INTRODUCTION}

Urinary tract infection (UTI) is the most common and a serious health problem both in the community and hospital settings each year worldwide. It is the most important cause of morbidity in the world affecting all age groups across the life span and in both genders and usually requires medical treatment. About 150 million people are diagnosed with UTI each year, costing the global economy in excess of 6 billion dollars. ${ }^{1}$
The emergence of antibiotic resistance in the management of UTI is a serious public health issue, particularly in the developing world where apart from high level of poverty, ignorance and poor hygienic practices, there is also a high prevalence of fake and spurious drugs of questionable quality in circulation. To ensure appropriate treatment, knowledge of the organisms that cause UTI and their antibiotic susceptibility is mandatory. ${ }^{2}$

Antibiotic resistance emerges commonly when patients are treated with empiric antimicrobial drugs. To overcome 
these difficulties and to improve the outcome of serious infections, monitoring of resistance patterns in the hospital is needed.

The present study is an attempt to analyse the antimicrobial sensitivity pattern of pathogens isolated from the urine samples of admitted patients suffering from UTI in Tripura Medical College and Dr. B.R. Ambedkar Memorial Teaching Hospital (TMC).

\section{METHODS}

The study was carried out at TMC, a 560 bedded tertiary care hospital located in the north eastern region of India. This was a hospital record based study. Before initiating the study, proper approval was taken from the Institutional Ethics Committee (IEC). The duration of the study was for one year. The data from October 2015 to September, 2016 were collected and analysed.

\section{Inclusion criteria}

The urine samples of clinically diagnosed UTI patients admitted in various departments of the hospital during the study period were included.

\section{Exclusion criteria}

Antimicrobial agents that were used infrequently or rarely for sensitivity testing were excluded from the study. The samples with no bacterial growth were also excluded. The samples were processed for culture and sensitivity testing in the Department of Microbiology. The cultured plates were examined after 24 hours and organisms were identified by their colonial morphology, Gram staining and appropriate biochemical tests using standard techniques. ${ }^{4}$
The reports of culture and sensitivity testing of the samples were collected. The results were interpreted according to the guidelines of the Clinical and Laboratory Standards Institute (CLSI). Antibiotic susceptibility of the isolates was determined by Modified Kirby - Bauer disc diffusion method, according to CLSI recommendations. The zones of inhibition were measured, and the organisms identified as sensitive or resistant based on standard criteria. ${ }^{5}$ Control strains were used for checking the quality of discs and reagents.

\section{Statistical analysis}

The results were expressed in percentages and analysed for statistical significance by Chi square test using EPI6 software. $\mathrm{P}$ value $<0.05$ was considered statistically significant.

\section{RESULTS}

Table 1: Common pathogens in urine samples $(n=752)$.

\begin{tabular}{|ll|}
\hline Common pathogens & \\
\hline Organisms & Number $(\%)$ \\
\hline Enterococcus & $329(43.75)$ \\
\hline E. coli & $214(28.45)$ \\
\hline Klebsiella & $112(14.89)$ \\
\hline Other Pathogens & $28(3.73)$ \\
\hline Staph aureus & $22(2.92)$ \\
\hline Acinetobacter & $17(2.26)$ \\
\hline Pseudomonas & $14(1.86)$ \\
\hline Citrobacter & $12(1.6)$ \\
\hline Enterobacter & $04(0.53)$ \\
\hline MRSA & \\
\hline
\end{tabular}

Table 2: Sensitivity pattern of Enterococcus.

\begin{tabular}{|lllll|}
\hline Anitimicrobial agents & Total urine samples & Sensitive (\%) & Resistant (\%) & Remarks \\
\hline Levofloxacin** & 320 & $31(9.69)$ & $289(90.31)$ & $\mathrm{R}$ \\
\hline Nitrofurantoin** & 304 & $185(60.86)$ & $119(39.14)$ & $\mathrm{S}$ \\
\hline Vancomycin $^{* *}$ & 300 & $286(95.33)$ & $14(4.67)$ & $\mathrm{S}$ \\
\hline Gentamicin** $^{* *}$ & 285 & $64(22.46)$ & $221(77.54)$ & $\mathrm{R}$ \\
\hline Linezolid** $^{* *}$ & $264(93.62)$ & $18(6.38)$ & $\mathrm{S}$ \\
\hline Gatifloxacin** & 282 & $16(6.72)$ & $222(93.28)$ & $\mathrm{R}$ \\
\hline Ampicillin** & 238 & $21(11.11)$ & $168(88.89)$ & $\mathrm{R}$ \\
\hline Teicoplanin & 189 & $127(98.44)$ & $02(1.55)$ & - \\
\hline Cefotaxime* & 129 & $29(35.80)$ & $52(64.20)$ & $\mathrm{R}$ \\
\hline Ciprofloxacin & 81 & $03(5.66)$ & $50(94.34)$ & - \\
\hline Amoxiclav & 53 & $05(11.63)$ & $38(88.37)$ & - \\
\hline Ceftriaxone & 43 & $05(11.90)$ & $37(88.10)$ & - \\
\hline Cefuroxime & 42 & $01(4.34)$ & $22(95.65)$ & - \\
\hline Cotrimoxazole & 23 & $11(78.57)$ & $03(21.43)$ & - \\
\hline Cefoxitin & 14 & $01(10)$ & $09(90)$ & - \\
\hline Norfloxacin & 10 & $02(40)$ & $03(60)$ & - \\
\hline
\end{tabular}

** $\mathrm{p}<0.001,{ }^{*} \mathrm{p}<0.05, \mathrm{~S}-$ Sensitive, R- Resistant 
Table 3: Sensitivity pattern of $E$. coli.

\begin{tabular}{|lllll|}
\hline Antimicrobial agents & Total urine samples & Sensitive (\%) & Resistant (\%) & Remarks \\
\hline Nitrofurantoin $^{* *}$ & 208 & $174(83.65)$ & $34(16.35)$ & $\mathrm{S}$ \\
\hline Imipenam** $^{*}$ & 199 & $146(73.37)$ & $53(26.63)$ & $\mathrm{S}$ \\
\hline Piperacillin/Tazobactam $^{* *}$ & 189 & $102(53.97)$ & $87(46.03)$ & - \\
\hline Ciprofloxacin $^{* *}$ & $31(16.58)$ & $156(83.42)$ & $\mathrm{R}$ \\
\hline Amoxyclav $^{* *}$ & 187 & $12(6.98)$ & $160(93.02)$ & $\mathrm{R}$ \\
\hline Amikacin** $^{* *}$ & 172 & $111(72.55)$ & $42(27.45)$ & $\mathrm{S}$ \\
\hline Gatifloxacin $^{* *}$ & 153 & $27(18.00)$ & $123(82.00)$ & $\mathrm{R}$ \\
\hline Cefuroxime $^{* *}$ & 150 & $10(7.04)$ & $132(92.96)$ & $\mathrm{R}$ \\
\hline Cefotaxime* & 142 & $21(17.50)$ & $99(82.50)$ & $\mathrm{R}$ \\
\hline Ceftriaxone** & 120 & $18(18.37)$ & $80(81.63)$ & $\mathrm{R}$ \\
\hline Gentamycin & 98 & $59(60.20)$ & $39(39.80)$ & - \\
\hline Levofloxacin $^{* *}$ & 98 & $7(9.33)$ & $68(90.67)$ & $\mathrm{R}$ \\
\hline Cefepime* & 75 & $19(28.79)$ & $47(71.21)$ & $\mathrm{R}$ \\
\hline Meropenem & 66 & $17(62.96)$ & $10(37.04)$ & - \\
\hline Cefpodoxime & 27 & $1(4.55)$ & $21(95.45)$ & - \\
\hline Norfloxacin & 22 & $1(11.11)$ & $8(88.89)$ & - \\
\hline
\end{tabular}

** $\mathrm{p}<0.001, * \mathrm{p}<0.05, \mathrm{~S}$ - Sensitive, R- Resistant

Table 4: Sensitivity pattern of Klebsiella.

\begin{tabular}{|llll|l|}
\hline Antimicrobial agents & Total urine samples & Sensitive (\%) & Resistant $(\%)$ & Remarks \\
\hline Nitrofurantoin $^{* *}$ & 107 & $35(32.71)$ & $72(67.29)$ & R \\
\hline Imipenem** $^{*}$ & 102 & $77(75.49)$ & $25(24.51)$ & $\mathrm{S}$ \\
\hline Ciprofloxacin & 98 & $44(44.90)$ & $54(55.10)$ & - \\
\hline Piperacillin/Tazobactam & 95 & $54(56.84)$ & $41(43.16)$ & - \\
\hline Amikacin & 90 & $51(56.67)$ & $39(43.33)$ & - \\
\hline Amoxyclav & 90 & $2(2.22)$ & $88(97.78)$ & - \\
\hline Gatifloxacin & 82 & $43(52.44)$ & $39(47.56)$ & - \\
\hline Cefotaxime** & 66 & $18(27.27)$ & $48(72.73)$ & $\mathrm{R}$ \\
\hline Cefuroxime & 53 & $5(9.43)$ & $48(90.57)$ & - \\
\hline Gentamycin & 49 & $26(53.06)$ & $23(46.94)$ & - \\
\hline Ceftriaxone & 36 & $8(22.22)$ & $28(77.78)$ & $\mathrm{R}$ \\
\hline Cefepime & 26 & $11(42.31)$ & $15(57.69)$ & - \\
\hline Levofloxacin & 25 & $8(32)$ & $17(68)$ & - \\
\hline Cefpodoxime & 10 & $1(10.00)$ & $9(90)$ & - \\
\hline Meropenem & 10 & $7(70)$ & $3(30)$ & - \\
\hline Norfloxacin & 3 & $2(66.67)$ & $1(33.33)$ & - \\
\hline
\end{tabular}

** $\mathrm{p}<0.001,{ }^{*} \mathrm{p}<0.05$, S- Sensitive, R- Resistant

During the 12 month study period, a total of 752 urine samples were analysed. Enterococcus (43.75\%) was the most frequently isolated bacteria, followed by $E$. coli $(28.45 \%)$ and Klebsiella $(14.89 \%)$. The common pathogens that were isolated from the urine sample are shown in Table 1.

Antibiotic sensitivity pattern of Enterococcus is as per Table 2. Enterococcus was highly sensitive $(\mathrm{p}<0.001)$ to vancomycin $(95.33 \%$,$) , linezolid (93.62 \%)$ and nitrofurantoin $(60.86 \%)$. The organism was highly resistant $(\mathrm{p}<0.001)$ to gatifloxacin $(93.28 \%)$, levofloxacin
(90.31\%), ampicillin (88.89\%), gentamicin (77.54\%), cefotaxime $(64.20 \%)$.

Antibiotic sensitivity pattern of $E$. coli is shown in Table 3. E. coli was mostly sensitive to nitrofurantoin $(83.65 \%)$, imipenem (73.37\%), amikacin (72.55\%). The microorganism was resistant to amoxyclav (93.02\%), cefuroxime $(92.96 \%)$, levofloxacin $(90.67 \%)$, ciprofloxacin $(83.42 \%)$, cefotaxime $(82.5 \%)$, gatifloxacin $(82 \%)$, ceftriaxone $(81.63 \%)$, cefepime $(71.21 \%)$. 
Antibiotic sensitivity pattern of Klebsiella is as per Table 4. The organism was mainly sensitive to imipenem $(75.49 \%)$ and resistant to ceftriaxone (77.78\%), cefotaxime $(72.73 \%)$, nitrofurantoin $(67.29 \%)$.

\section{DISCUSSION}

The present study showed the types of bacterial pathogens and the antibiotic sensitivity pattern of these pathogens isolated from urine sample of admitted patients suffering from UTI. Enterococcus was the predominant microorganism isolated from these samples (43.75\%). This was comparable to the findings of Atray D et al. ${ }^{6}$ Chakraborty et al, conducted a study in Kolkata which also showed enterococcus was the predominant organism $(66 \%)$ isolated from urine samples. ${ }^{7}$ In this study, the other common pathogens isolated were E. coli $(28.45 \%)$ and Klebsiella (14.89\%). These finding correlates with the findings of Bharti et al, where the prevalence of $E$. coli and Klebsiella was found to be $36.84 \%$ and $7.66 \%$ respectively. ${ }^{8}$

In this study, Enterococcus was mostly sensitive to vancomycin $(95.33 \%)$ and linezolid $(93.62 \%)$ which was similar to the findings of other studies. ${ }^{8,9}$

In the present study E. coli was sensitive to nitrofurantoin, imipenem and amikacin which was contrary to the findings of Pattanayak $\mathrm{C}$ et al, who found that the organism was mainly sensitive to polymixin B, gatifloxacin, ceftriaxone. ${ }^{10}$ In this study, E. coli was mostly resistant to cephalosporins which is consistent with the findings of other studies. ${ }^{11}$

Klebsiella was also resistant to most of the antibiotics including cephalosporins and sensitive to imipenem. Similar findings regarding drug resistance pattern of Klebsiella was also observed by other researchers. ${ }^{12}$ The most effective antimicrobial agents in this study were imipenem, nitrofurantoin, amikacin, for Gram negative bacilli. However, isolated Gram positive cocci were fully sensitive to vancomycin, linezolid and nitrofurantoin.

\section{CONCLUSION}

The study showed that positive urine culture with the antibiotic sensitivity of the isolates is very important for antimicrobial therapy, as antibiotic resistance is a worldwide problem which causes ineffectiveness of treatment. Early and proper treatment can decrease the antibiotic resistance. This study will also help in assuming the emerging trends in resistance at the local level to support clinical decision making, infection - control interventions, and antimicrobial - resistance containment strategies.

\section{ACKNOWLEDGEMENTS}

Authors would like to acknowledge the Principal, Tripura Medical College and Dr. B.R. Ambedkar Memorial
Teaching Hospital, Agartala, Tripura for providing the necessary facilities to carry out this study.

Funding: No funding sources

Conflict of interest: None declared

Ethical approval: The study was approved by the Institutional Ethics Committee

\section{REFERENCES}

1. Rangari AA, Sharma S, Tyagi N, Singh P, Singh G, Thakur R. Antibiotic Susceptibility Pattern of Bacterial Uropathogens Isolated from Patients at a Tertiary Care Hospital in Western Uttar Pradesh of India. Int J Curr Microbiol App Sci. 2015;4(10):64657.

2. Abubakar EM. Antimicrobial susceptibility pattern of pathogenic bacteria causing urinary tract infections at the Specialist Hospital, Yola, Adamawa State, Nigeria. Journal of Clinical Medicine Research. 2009;1(1):001-8.

3. Chaudhary BL, Srivastava S, Singh BN, Shukla S. Nosocomial Infection due to Multidrug Resistant (MDR) Escherichia coli and Klebsiella pneumonia in Intensive Care Unit. International Journal of Current Microbiology and Applied Sciences. 2014;3(8):630-5.

4. Choudhury D, Chakravarty P. Prevalence and antimicrobial susceptibility pattern of methicillin resistant Staphylococcus aureus in Silchar Medical College and Hospital, Assam, India. Int J Basic Clin Pharmacol. 2016;5:2174-7.

5. Konman EW, Allen SD, Janda WM, Schreckenberger PC, Winn Jr WC. Color atlas and textbook of Diagnostic Microbiology, $5^{\text {th }}$ Ed. Philadelphia: Lippincott - Raven; 1997.

6. Atray D, Sharma A1, Atray M. Prevalence of enterococci and its antibiotic resistance in various clinical samples at tertiary care hospital in southern Rajasthan, India. Int J Res Med Sci. 2016;4(8):34136.

7. Chakraborty A, Pal NK, Sarkar S, Gupta MS. Antibiotic resistance pattern of Enterococci isolates from nosocomial infections in a tertiary care hospital in Eastern India. J Nat Sci Biol Med. 2015;6(2):394-7.

8. Bharti AK, Farooq U, Singh S, Kaur N, Ahmed R, Singh K. Incidence of Enterococcal Urinary Tract Infection and its Sensitivity Pattern among Patients Attending Teerthanker Mahaveer Medical College and Research Centre, Moradabad, India. Int J Sci Stud. 2016;3(12):115-9.

9. Abdulla EF, Abdulla ME. Antibiotic option for Enterococcus faecalis infections. Pak J Med Sci. 2006;22:286-90.

10. Pattanayak C, Patanaik SK, Datta PP, Panda P. A study on antibiotic sensitivity pattern of bacterial isolates in the intensive care unit of a tertiary care hospital in Eastern India. Int J Basic Clin Pharmacol. 2013;2:153-9.

11. Barai L, Fatema K, Ashraful Haq J, Omar Faruq M, Areef Ahsan ASM, Golam Morshed MAH, et al. 
Bacterial profile and their antimicrobial resistance pattern in an intensive care unit of a tertiary care hospital in Dhaka. Ibrahim Med Coll J. 2010;4:66-9.

12. Shalini S, Kranthi K, Gopalkrishna BK. The microbiological profile of nosocomial infections in the intensive care unit. J Clin Diagn Res. 2010;4:3109-12.
Cite this article as: Das UK, Bhattacharjee $P$, Debnath S, Chakraborty M, Ghosh R, Das L, et al. Antibiotic sensitivity pattern of bacterial isolates from urine samples of admitted patients with urinary tract infection in a tertiary care teaching hospital of Tripura, India: a hospital record based study. Int J Basic Clin Pharmacol 2018;7:585-9. 